\title{
A Late Triassic dinosaur-dominated ichnofauna from the Tomanová Formation of the Tatra Mountains, Central Europe
}

Grzegorz Niedźwiedzki

Acta Palaeontologica Polonica 56 (2), 2011: 291-300 doi: http://dx.doi.org/10.4202/app.2010.0027

Osteological fossils of dinosaurs are relatively rare in the Late Triassic and Early Jurassic. Thus, ichnofossils are a critical source of information on Late Triassic terrestrial vertebrate communities. The outcrops of the Tomanová Formation (?late Norian-Rhaetian) in the Tatra Mountains of Poland and Slovakia have yielded a diverse ichnofauna. Seven more or less distinct morphotypes of dinosaur tracks have been recognized and are discussed. Most tracks are partly eroded or deformed, but are preserved well enough to be assigned to a range of trackmakers, including early ornithischians, small and large theropods (coelophysoids and/or possibly early tetanurans), and probably basal sauropodomorphs ("prosauropods") or first true sauropods.

Key words: dinosaur tracks, paleoichnology, Upper Triassic, Tatra Mountains, Poland, Slovakia.

Grzegorz Niedźwiedzki [gniedzwiedzki@ biol.uw.edu.pl], Department of Paleobiology and Evolution, University of Warsaw, Banacha 2, 02-097 Warszawa, Poland and Institute of Paleobiology PAS, Twarda 51/55, 00-818 Warszawa.

This is an open-access article distributed under the terms of the Creative Commons Attribution License (for details please see creativecommons.org), which permits unrestricted use, distribution, and reproduction in any medium, provided the original author and source are credited. 